\title{
A BEVÁSÁRLÓ KÖZÖSSÉG FOGALMI MEGKÖZELÍTÉSE MAGYARORSZÁGON
} DEFINITIONS OF THE SHOPPING COMMUNITY IN HUNGARY

\author{
Kápolnai Zsombor ${ }^{1}$, Nagyné Dr. Molnár Melinda ${ }^{2}$ \\ ${ }^{1} \mathrm{PhD}$ hallgató, ${ }^{2}$ egyetemi docens \\ ${ }^{1}$ Szent István Egyetem, Gazdaság- és Társadalomtudományi Kar, Enyedi György Regionális \\ Tudományok Doktori Iskola, ${ }^{2}$ Szent István Egyetem, Gazdaság- és Társadalomtudományi \\ Kar, \\ E-mail: ${ }^{1}$ kapolnaizsombor@gmail.com, ${ }^{2}$ nagyne.molnar.melinda@gtk.szie.hu
}

\section{Összefoglalás}

A bevásárló közösség Magyarországon a 21. század második évtizedében széles körü népszerüségnek örvendő vásárlási forma. Míg a szakirodalom a rövid ellátási lánc egyik elemeként jelöli meg a bevásárló közösséget, addig a bevásárló közösségek magukat többek között „kapcsolatként”, vásárlási formaként, helyi gazdaságfejlesztés eszközeként jelenítik meg A bevásárló közösségek szervezésének alapja a tudatos vásárlók megléte, megteremtése. Ez a tevékeny közösség Magyarországon elsőként a fövárosban valósult meg. Innen terjedt tovább, először föként vidéki városokba: Debrecenbe, Kecskemétre, Nyíregyházára. Mára kisebb lakosságszámmal bíró településeken, mint Csákvár vagy Csömör is müködik bevásárló közösség. A tanulmány a bevásárló közösséggel, mint a rövid ellátási lánc újszerü formájával foglalkozik (Szabó, 2016), annak mindenekelőtt a fogalmi megközelítéseivel. A bemutatásra váró helyzetkép elsősorban a Magyarországon müködő bevásárló közösségek sajátosságaira épít.

\begin{abstract}
Today's short supply systems were first introduced in France, Italy and England in the 1980s, and since 2008 they have been on the rise again. (Kujani 2015). The global economic crisis has pointed the public's awareness to the vulnerability of economic systems thinking in global solutions, and to the importance of self-sufficiency and short supply chains. (Rapkay et al 2013). The elements of the short supply chain have become increasingly popular in Hungary. The study attempts to define conceptually the shopping community among the novel forms (Szabó 2016) of the short supply chain.
\end{abstract}

Kulcsszavak: REL, helyi termék, bevásárló közösség

JEL besorolás: R11

LCC: $H T 388$

\section{Bevezetés}

A mai értelemben vett rövid ellátási rendszerek Franciaországban, Olaszországban és Angliában az 1980-as években jelentek meg, de a kétezres évek végétől ismételten reneszánszukat élik (Kujáni 2015). Ennek oka, hogy a világgazdasági válság Európa szerte rávilágította a közvélemény figyelmét a globális megoldásokban gondolkodó gazdasági rendszerek sebezhetőségére, valamint az önellátás, a rövid ellátási láncok fontosságára (Rapkay et al 2013). 
A rövid ellátási láncok fontosságát mutatja, hogy az Európai Unió vidékfejlesztési programjában is helyet kap. A magyar gyakorlatban a Vidékfejlesztési Program egyik alprogramjaként szerepel a rövid ellátási láncok fejlesztése (Kujáni, 2015). Láthatóan Magyarországon a rövid ellátási lánc szerepe az elmúlt évtizedben egyértelmüen felértékelődött (Szabó 2016, Kujáni, 2015, Vidékstratégia, 2012). Napjainkban az élelmiszerkereskedelemben vezető pozíciót betöltő kiskereskedelmi áruházak, bevásárló központok mellett az alternatív, személyes kapcsolatokra és bizalomra épülő rendszer is kiépülöben van.

Az endogén erőforrások szerepe az elmúlt két évtizedben Magyarországon is felértékelödött a gazdaságfejlesztésben (Káposzta, 2007), ez a helyi termék értékesítésére is pozitív hatást gyakorolt. A helyi termék, mely a rövid ellátási lánc fontos összetevője, 2010 óta kitüntetett szerepet játszik a magyar vidék életében. A helyi termékeknek az a sajátossága, hogy az előállításuk helyén, és attól távol is van lehetőség az értékesítésre. Az is tapasztalati tény, hogy a több helyi terméket kínáló közösségi összefogások eredményesebbek, mint az egyéni akciók. (Kápolnai, 2017).

\section{Anyag és módszer}

A Központi Statisztikai Hivatal adatbázisában a rövid ellátási rendszerek formái jelenleg nem kerülnek gyüjtésre. A rövid ellátási láncokat tekintve a több évtizedes hagyományokkal rendelkező Európai uniós országokban, valamint az Eurostat szintjén sem folyik a témában adatgyüjtés.

A felmérés és elemzés éppen ezért alapvetően puha-módszerekre támaszkodik. A gyüjtőmunka gerincét tartalomelemzés és interjúval történő információgyüjtés adja. Az interjú mindenekelött a problémafelvetés irányainak kijelölésében volt fontos. A legfontosabb interjúalany a Kecskeméti Szatyor Egyesület gazdasági ügyekért felelős elnökségi tagja, Rátkai Edit volt.

Ami a tartalomelemzést illeti, ez egy olyan kutatási eljárás, amely segítségével a szövegadatokból olyan következtetések vonhatók le, amelyek a közleményekben nyíltan nincsenek kimondva, de a szöveg szerkezetéből, az elemek együttes elöfordulásából és azok törvényszerüen visszatérő sajátosságaiból kiolvashatók (Kérdő, 2008). Ez a módszer azért bizonyult alkalmasnak, mert adatgyüjtés a bevásárló közösségekről nem folyik, ami rendelkezésre áll, az a Tudatos Vásárlók Egyesülete által közzétett lista. Ez a ma legtöbbet hivatkozott, bevásárló közösségeket, dobozrendszereket is magában foglaló adatbázis TUDATOS VÁSÁRLÓ (2019b). Ebben fővárosi és vidéki településeken elindult bevásárló közösségek szerepelnek: Batyor a bajai szatyor közösség, Borsodi Kosár Kör, Csömöri Éléskamra, Félegyházi Szatyorklub, Gördülő Kosár, Kecskeméti Szatyor Egyesület, Kiskosár Bevásárló Közösség, Miskolci Zöld Kosár, Natúrkosár, Nyíregyházi Kosár Közösség, Szatyor Bolt, Szatyor Debrecen Szigetközi Szatyor Közösség. A vizsgálat során ez a lista volt tehát a kiindulópont. Az ebben szereplö bevásárló közösségek képezték a vizsgálati egységeket. Itt fontos megjegyezni, hogy az Esztergomban müködő Kiskosár bevásárló közösség által kiadott „Egyél velünk helyit” kiadványban is találunk egy bevásárló közösségeket tartalmazó adatbázist, mely néhány pontban eltér a Tudatos Vásárlók Egyesülete által kezelt adatbázistól, de a legtöbbet hivatkozott forrás a fent nevezett Tudatos Vásárlók Közössége által végzett gyüjtés.

A közzétett listával az elsődleges cél az volt, hogy az ott szereplö közösségek által megfogalmazott „,bevásárló közösség” definíciók rendszerezésre kerüljenek. Mivel azonban tapasztalati tény, hogy bár több, a hazai fejlesztéspolitikát érintő dokumentum (Nemzeti Vidékstratégia), valamint állami kutató intézetek, mint az AKI is kiindulási alapként fogadja el 
a Tudatos Vásárlók Egyesülete által összeállított bevásárló közösség adatbázisát; azonban ennél sokkal több közösség van ténylegesen. Olyan bevásárló közösségek sem jelennek meg benne, amelyek egyébként a tapasztalatok szerint jelentős taglétszámmal rendelkeznek. Ilyen közösség többek között a Keszthelyi Cekker Bevásárló Közösség, Bácsalmási Bevásárló Közösség, az Esztergomi Kiskosár, a Váczi Kosár Közösség, Pázmándi Spájz, Vértesi Kamra, Tatai Forrás Bevásárló Közösség. Ebből kiindulva második lépésben megtörtént a listán nem szereplő bevásárló közösségek felkutatása is. Ezután lehetőség nyílt nemcsak a lista szereplőinek anyagaival dolgozni.

A kutatás során internetes tartalomelemzésre került sor, melynek keretében összesen 25 bevásárló közösség honlap facebook oldalának elemzésére került sor azzal a céllal, hogy müködésük dinamikáját, és az általuk használt marketingeszközöket is rendszerezni lehessen a későbbiek során.

Ugyancsak önálló kutatási gyakorlat volt a részvevő megfigyelés, aminek során az Esztergomban tevékenykedö Kiskosár Bevásárló Közösség müködésének gyakorlatát is tanulmányoztuk. Azért éppen ennek a bemutatására kerül sor, mert a Kiskosár Bevásárló közösség több éves, rentábilis müködése, a folyamatos ellátás biztosítása alapján, a digitális termelői piacok egyfajta előfutárának is tekinthető.

\section{Eredmények}

\section{A bevásárló közösség fogalmi tisztázása tartalom-elemzés alapján}

A bevásárló közösség fogalmi meghatározása a rövid ellátási lánc más elemeihez hasonlóan vö. helyi termék, nem egyszerü feladat. Számos megfogalmazás igyekezett az utóbbi években leírni a jelenséget. (G.Fekete, 2009, Czene-Ricz 2010, Handlerné et al 2012, Kápolnai, 2017, Ritter -Nagy-Tóth 2012, Helyi Termék Kézikönyve, 2015) Annyi bizonyos, hogy a bevásárlóközösségek szorosan kapcsolódnak a rövid ellátási lánc működéséhez.

A bevásárló közösségek értelmezésekor sokféle tudományos irányból indulhatunk el; például az agrárgazdaság, földrajz, közgazdaságtan, szociológiai, humánökológia stb. nézőpontjaiból. A különböző tudományos szereplők eltérően definiálják a bevásárló közösséget. A gyakorlati szereplők a tudományos megközelítéseket magukra szabva, ,átírva”alkalmazzák.

Elsőként érdemes tisztázni a fogalmi alapokat. Az összetett szó két részét külön vizsgálva a „,bevásárló” vagy vásárló döntést hozó személy, aki valamilyen szükségletet elégíti ki. Az Új Magyar Lexikon így ír a közösségröl 1962-ben: „társadalmi csoport, amelyet az alkalmi v. csupán korlátolt célokra alakult társulásokkal szemben a közös érdekek alapján nagyfokú állandóság, az élet számos területére kiterjedő összetartozási tudat és együttmüködés, többnyire közös eszmék birtoka is jellemez” (Új Magyar Lexikon K-Me 4. kötet 455 p). A „közösség” egyike a teret alakító és legalapvetőbb társadalmi funkcióknak (Berényi, 1992). A közösségek gazdasági szerepére világít rá G. Fekete Éva és Siposné Nándori Eszter (2013): „A közösségek, a természetes és szervezett társadalmi csoportok, hálózatok a jólléthez szükséges „társas lét”en kívül a gazdaság szempontjából is fontos társadalmi tőke elsődleges forrásait is jelentik." (G.Fekete-Siposné 2013. 19.p.)

Induljunk ki abból, hogy a bevásárló közösség fogalmának beazonosításához legpraktikusabb, ha a müködő bevásárló közösségek által használt meghatározásokat vesszük alapul. A bevásárló közösség, mint a rövid ellátási lánc eleme, a kétezres évektől jelenik meg Magyarországon civil kezdeményezés eredményeként. A bevásárló közösségek hazai listáját is 
összeállító Tudatos Vásárlók Egyesülete foglalkozik a fogalmi megközelítésekkel, amennyiben a közösségi gazdaság, a dobozrendszer és a bevásárló közösség definícióját is megadja, bár ezek egymáshoz való viszonyára ugyanakkor nem mutat rá.

A közösségi gazdaság fogalmához megfogalmazza, hogy a vásárló egy egész szezonra csatlakozik a gazdához, és vállalja, hogy minden héten átveszi, ami a gazdaságban megtermett. A termékek és azok mennyisége is változó, idénytől függően. A vásárló átalánydíjat fizet a mindig változó termékekért. A mennyiség természetesen változó, nyár végén sokkal több mindent lehet hazavinni, mint tavasszal.

A dobozrendszerről a nevezett oldal azt írja, hogy a közösségi gazdasággal szemben hetente kínál választási lehetőséget a vásárlónak. Azaz hetente azt kaphatja meg a vásárló a dobozban fix áron, ami éppen megtermett a gazdaságban. A közösségi gazdaságokkal ellentétben azonban hetente eldönthetö, hogy rendelünk dobozt vagy nem.

A bevásárló közösségek meghatározásában a döntő, hogy a vásárló hetente választhatja ki, hogy egy adott listáról milyen termékből és mennyit rendel a környékbeli gazdáktól.

Most vizsgáljuk meg, hogy a legismertebb magyarországi bevásárló közösség, a Szatyorboltot is müködtető Szatyor Egyesület miként értelmezi a bevásárló közösség fogalmát! Fontos megjegyezni, hogy az Egyesület előzményét a Tudatos Vásárlók Egyesülete néhány tagjának köszönheti, akik már 2005-ben elkezdték a bevásárló közösség megszervezését, amely nem vezetett eredményre (Kajner-Lányi-Takács 2013). A Szatyor Egyesület a bevásárló közösséget laza csoportként definiálja, melynek tagjai a számukra szükséges mennyiségü élelmiszert fogyasztják el, valamint az élelmiszer termelés teljes folyamatába betekintést engednek a vásárlóknak. A bevásárló közösséget hosszú távon vásárlási formaként képzeli el. (SZATYORBOLT, 2019a).

A Szatyor Egyesület egyik alapítója Kármán Erika egy interjúban a Szatyor bevásárló közösséget a „bolt” előzményeként értelmezte- utalva arra, hogy a bevásárló közösség egyik eleme a tudatos vásárlásnak., amelynél a bolt magasabb szervezettségi szintet képvisel SZATYORBOLT (2019b).

A következőkben érdemes megvizsgálni, hogy mi a lényege a tudatos vásárlásnak. A fogyasztóvédelem, valamint a hazai Tudatos Vásárlók Egyesülete által megfogalmazott definíció így szól:„,klasszikus fogyasztóvédelem szerint tudatos vásárló az, aki nem hagyja, hogy átverjék. Aki tisztában van fogyasztói jogaival, és él is velük. Aki tájékozódik az árakról, a termékek minőségéről, a kapcsolódó szolgáltatásokról, és a legjobb ajánlatot választja ki” (TUDATOS VÁSÁRLÓ 2019a).

A Tudatos Vásárlók Egyesülete megfogalmazásában a tudatos vásárlás ökológiai és etikai szempontokat is hordoz: „Fontos, hogy etikailag és környezetileg is tudatosak legyünk, ami azt jelenti, hogy saját magunkon túl másokra is tekintettel vagyunk. Ezek a mások lehetnek ma élő emberek, vagy a jövőben megszületendő gyermekeink, unokáink, vagy nem emberi létezők: állatok, növények, sőt, ökológiai rendszerek. Mi, tudatos vásárlók tehát olyan fogyasztói döntéseket próbálunk hozni, amelyekkel nem csak mi járunk jól, hanem - fogalmazzunk egyszerüen - a világ is. Döntéseink alapvető értékeket tükröznek: hitünket az igazságosságban, a méltányosságban, az ökológiai felelősségben.” A Tudatos Vásárlók Egyesülete által használt definíció a fenntartható fejlődés 1987-ben a Brundtland-jelentésben megfogalmazott definícióját terjeszti ki a vásárlásra (UNESCO, 2009). 
A Szatyor bevásárló közösség mintájára több vidéki nagyvárosban (Kecskemét, Debrecen) szatyor név alatt jöttek létre bevásárló közösségek. Ezen szervezetek a fővárosban müködő modellt vették át a helyi igényekre alakítva. Vannak nagyon minimalista besárló közösségmegfogalmazások is: a Debreceni és a Kecskeméti Szatyor például önmagát egyszerủen „kapcsolatként” definiálja, nem végez sem kereskedelmi sem szolgáltató tevékenységet.6 Kétségtelen tény, hogy a bevásárló közösségek egyik legfontosabb jellemzője a „kapcsolat” a vevő és az eladó között, bár az is tapasztalat, hogy a bevásárló közösség honlapja maga is egy szolgáltatás.

A továbbiakban érdemes körüljárni, hogy a bevásárló közösség valóban felfogható-e egy a boltrendszert megelöző kezdetleges kereskedelmi közvetítő formának? A tapasztalatok azt mutatják, hogy elméletileg megvan arra a lehetőség, hogy egy bevásárló közösség fejlődéstörténete elvezessen valamilyen bolt(hálózat) kialakulásához. De nem szükségszerüen. Ráadásul fontos megjegyezni azt is, hogy olyan is van, amikor egy bolti kereskedelemmé fejlödött bevásárló-közösség visszaalakul a hagyományos bolt nélküli bevásárló-közösségi szintre. Ez a tudatos „visszafejlesztés” jelent meg például a budapesti Szatyorbolt esetében is 2019 januárjától. Az utóbbi években a Szatyorbolt vásárlói átvételkor már nem találkoztak személyesen a termelőkkel, így a vevők és termelők közötti közvetlen kapcsolat nem valósult meg. Persze az is igaz, hogy 2019-töl ismételten erösíteni kívánja a Szatyorbolt a vevők és termelők közötti közvetlen kapcsolatot. A bevásárló közösségek tevékenységének sarkalatos pontja ugyanis a közvetlen kapcsolat fenntartása. A Szatyorbolt tehát 2019-től úgy müködik, hogy lesz közvetlen találkozás vevők és termelők közt: a „dobozok,” melyeket a vevők a Szatyorboltban vesznek át heti rendszerességgel- ismételten a Szatyorboltban kerülnek majd összeállításra a termelőkkel közösen. Így a vásárlók nem pusztán az összeállított „dobozokat” kapják meg, hanem a termelökkel is személyesen találkozhatnak. Ugyancsak a termelöi kínálat és a vevő találkozását segíti, hogy a Szatyorboltban 2019-től ismételten fog müködni az ún. Mini-Piac, melynek keretében hétről-hétre más termelö kínálja személyesen is a termékeit (SZATYOR EGYESÜLET, 2019)

A Szatyorbolt fentiekben bemutatott példája azt mutatja, hogy a bevásárló-közösség egy sajátos kereskedelmi közvetítő forma. Ezzel cseng össze az egyik legfiatalabb magyarországi bevásárló közösség megfogalmazása is, mely 2018 őszén indult Tatai Portéka néven. Igaz, hogy vásárlási formaként nevezi meg a tevékenységet, de lényegében ugyanarról beszél, mint a Szatyorbolt. „A bevásárló közösség olyan vásárlási forma, amely biztosítja a vevők és a termelők közvetlen kapcsolatát, ezen keresztül a kereslet és a kínálat még hatékonyabb találkozását. A vásárlás elöre leadott rendeléseken keresztül történik, szem elött tartva a közösség és a környezet érdekeit is" (TATA BEVÁSÁRLÓ KÖZÖSSÉG ,2019).

Az Esztergomi Kiskosár Közösség kicsit máshová teszi a meghatározásban a hangsúlyt: a bevásárló közösséget a helyi termékekhez való hozzájutás egy újszerű módjának, a rövid élelmiszer ellátási lánc egyik formájaként definiálja. (KISKOSAR, 2019). Ez a megfogalmazás köszön vissza az Egyél helyit címmel kiadott bevásárló közösségek indítását segítő kiadványban is, melyben több hazai bevásárló közösség is bemutatásra kerül. (Egyél helyit, 2017). A Nyíregyházi Kosár Bevásárló Közösség szintén a helyi termékek népszerüsítését, valamint a helyi gazdaság fejlesztését tartja a legfontosabbnak (NYÍREGYHÁZI KOSÁR, 2019). Az Érden alakult Natúrkosár Bevásárló Közösség a célkitüzései lényegeként azt fogalmazta meg, hogy a cél az, hogy a célcsoportokhoz közvetlenül a környék termelöitöl eljussanak a friss, organikus gazdálkodásból származó élelmiszerei (ÉRD BEVEÁSÁRLÓ KÖZÖSSÉG,2019). A Borsodi Kosár Kör- mely az előbb említett Natúrkosárhoz hasonlóan már nem müködik, azonban müködésük során az élelmiszer előállítók mellett kézmủvesek 
csatlakozását is várta -a csere és vásárlókörhöz. A csere- fogalma a vizsgált bevásárlóközösségek között kizárólag itt jelent meg (BORSOD 2019).

Érdekesség, hogy a bevásárló közösség, mint elnevezés napjainkban marketing elemként is megjelenik az outlethez hasonlóan. Sok esetben csak nyomokban követve az alapelveket. Ilyen például a budapesti agglomerációban vállalkozásként müködő enkosaram.hu., mely átvevő pontokkal rendelkezik, azonban csoport nem kapcsolódik a „közösséghez”.

Rendkívül fontos tapasztalati tény, hogy a bevásárló közösség fogalmi meghatározása ugyanannak a közösségnek az életében is változik. Ennek fö oka, hogy szükségszerüen átalakulások jellemzik a bevásárló közösségek formálódását a fejlődésük során. A 2011-ben indult Csömöri Éléskamra Bevásárló Közösség például a megnövekedett vásárlói érdeklődés miatt már nem tudta az előrendelést és a termékek-átadását koordinálni, így a tagok úgy döntöttek, hogy termelöi piacként müködnek tovább (Ujszászi 2013). A csömöri bevásárló közösség termelöi piaca 2013 szeptembere óta müködik. A termelői piacon egyes árusoknál továbbra is lehet előzetesen rendelni, azonban a közösségnek ez már nem elsődleges funkciója.

A témához szorosan kapcsolódó termelői piacok életciklusáról részletesein ír Szabó Dorottya (Szabó 2016). A bevásárló-közösségek példáit vizsgálva is igazolódik, hogy a bevásárló közösségek müködésében is tapasztalható egyfajta életciklus.

A gyakorlatban müködő bevásárló közösségek a helyi termelők támogatását, a vásárlók teljeskörü információkkal történő ellátását tartják a bevásárló közösségek jellemzőinek (ÉN KOSARAM 2019).

A bevásárló közösséget a helyi termék értékesítésének egy formájaként is értelmezhetjük. A bevásárló közösség gyüjtőfogalomként jelenik meg Magyarországon, mely számos tevékenységet magában foglal, amelyeket a szakirodalom a bevásárló közösségekkel együtt a rövid ellátási lánc elemeiként jelenít meg (Vidékstratégia 2012).

\section{A bevásárló közösség müködésének gyakorlata általában}

\section{A müködés jogi, technikai kerete}

Az első fontos tudnivaló, hogy a bevásárló közösségek működtetését jellemzően valamilyen civil szervezet, vagy egyházközség biztosítja. Az Ister-Granum Eurorégióval összhangban müködő Kiskosár Bevásárló Közösséget például az Esztergomi Környezetkultúra Egyesület müködteti. Az Egyesület célkitüzése és fö tevékenysége a lakosság átfogó környezeti szemléletformálása. "Kiemelt fókuszterületünk a fenntartható fogyasztást megvalósító közösségek szervezése, környezeti nevelési programok szervezése (elöadások oktatási intézményekben).” olvasható az Egyesület bemutatkozásában.

Számos jogi feltételnek kell megfelelni. A termelő és fogyasztó közötti árucserét biztosító ú.n. átadási helynek meg kell felelni az élelmiszerek tárolásáról szóló jogszabályoknak, például a hütött tárolásra, higiéniára vonatkozó előírásoknak.

A bevásárló közösségek élelmiszerbiztonsági téren, számlavezetési biztonság terén azonban nem a szokásos módon müködnek, éppen ezért a NÉBIH, NAV munkatársai számára kihívást jelent a bevásárló közösség, és a hozzá hasonló rendszerek ellenőrzésének, ellenőrizhetőségének kimunkálása. 
A müködés technikai kerete, hogy a közösség jellemzően online felületet tart fenn, többek között a tájékoztatás, információáramlás, és legföképp a vásárlók elörendelésének leadása céljával.

\section{A müködés gyakorlata}

A müködés gyakorlata az, hogy miután a vásárlók az elörendelést leadták, ezt követően a bevásárló közösség önkéntesei- néhány esetben munkatársai is vannak a szervezetnektovábbítják a termelők felé a kért rendeléseket. A termelők a kért mennyiséget beszállítják az átadási helyre. A jól bevált gyakorlat az, hogy a bevásárló közösség önkéntesei állítják össze a vásárlók által rendelt csomagot. A vásárlók az átadási napon előre meghatározott időkeretben általában 2 vagy 4 órán keresztül vehetik át a terméket. Mivel a helyszínen történik a fizetés, ezért egyfajta bizalmi rendszerről beszélünk. A jól müködő bizalmi rendszer fokmérője, hogy mint a vizsgált közösségekben az átvétel elmaradását marginális számban tapasztalták csupán. Arra is találunk példát Magyarországon, hogy a bevásárló közösség bizományként tudja átvenni a terméket a termelőtől, azaz a fizetés egyhetes ütemezéssel zajlik. Ez az adóhatóság által is engedélyezett gyakorlat például a Nyíregyházi Kosárközösség által müködtetett bevásárló közösség működése során valósul meg (nyiregyhazikosar.hu). Helyszíni vásárlásra az esetek többségében nincs lehetőség. Az 1. ábra az esztergomi Kiskosár Bevásárló Közösség példáján keresztül mutatja be az említett általános gyakorlatot.

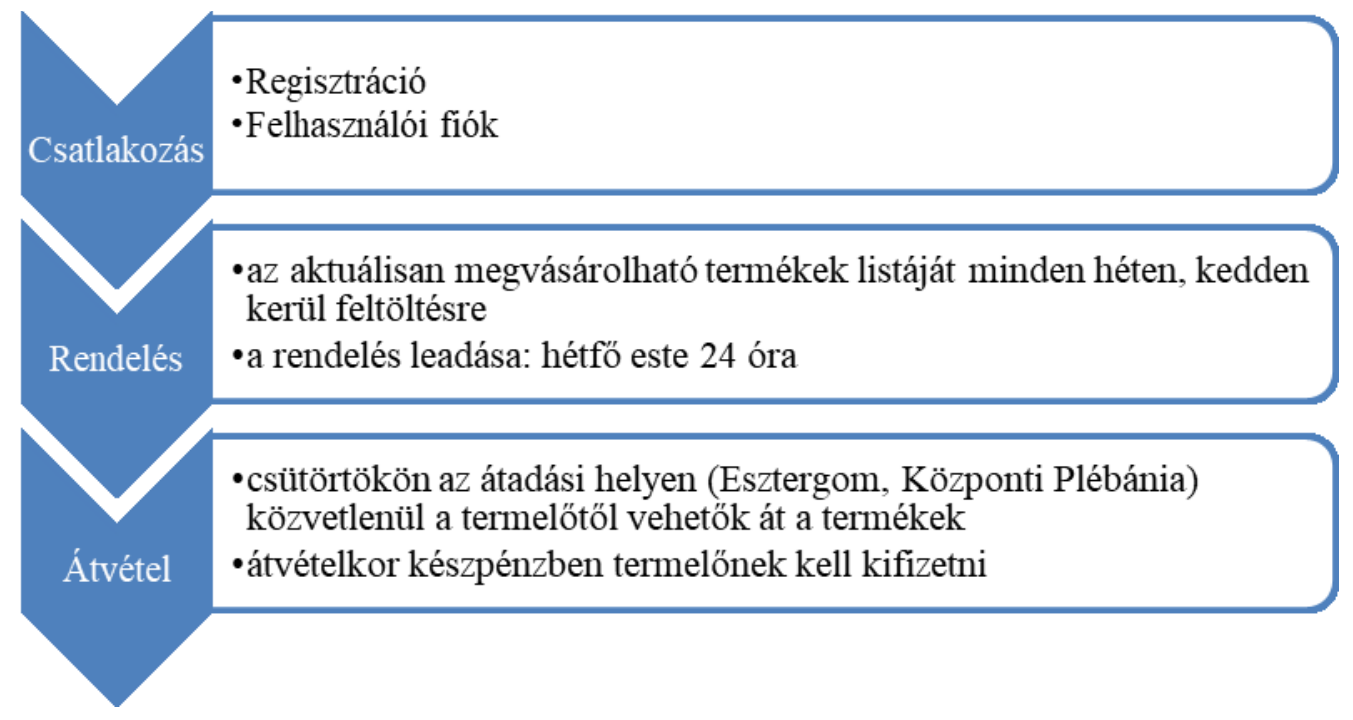

1. ábra. Az esztergomi Kiskosár Bevásárló Közösség müködése

Forrás: tartalom-elemzés alapján szerkesztette Kápolnai Zsombor

\section{A bevásárló közösség müködésének gyakorlata az esztergomi Kiskosár Bevásárló Közösség példáján}

A Kiskosár bevásárló közösség honlapja egy webshophoz hasonlóan müködik. A vásárlók a termék árát, fényképét, a termelő nevét, valamint a termelésnek az átadási ponttól mért távolságát is megismerhetik. Mivel a bevásárló közösség elsősorban a szemléletformálás egyik eszköze- a helyi termékek továbbá a rövid ellátási lánc népszerüsítése érdekében így a kistermelök mellett akár vállalkozók számára is lehetőséget biztosíthatnak termékeik értékesítésére. Ezért fontos jelezni a vásárlók számára, melyek azok a termékek melyek az ún. kistermelői rendeletben foglaltak alapján a 40 kilométer sugarú körön belülről származnak. 
A rövid ellátási lánc menedzselése, és az Ister Granum Eurorégió müködése szempontjából is fontos tényező a határon átnyúló partnerségi kapcsolatok kiépítése. A Kiskosár Bevásárló Közösség másik fontos közösségi sajátossága, hogy partnere a katolikus egyház. A bevásárló közösség átadási helyszíne Esztergomban ugyanis a belvárosi plébánia udvara. Az egyházi szerepvállalás a fizikai segítség mellett a bevásárló közösség társadalmi elismertségének növekedését is elősegíti. A történelmi egyházak patronálásával úgy véljük a bevásárló közösségek nem csupán egy rövid ellátási lánc támogatójával gazdagodnak, hanem bővül a szemléletformáló tevékenységük. Egymás mellé kerül a rövid ellátási lánc, a természetes alapanyagok és az ehhez kapcsolódó helyi termékek, a keresztény értékközösség támogatása, ami nagyszámú érdeklődőt, vásárlót és esetlegesen termelőt is vonzhat. Az eset nem egyedi: hasonló kezdeményezést ismerünk Vácon is.

A bevásárló közösség egyik előnye, hogy a kínálata tervezhető, így a vásárlót kevésbé érik váratlan szituációk, mint egy termelői vagy hagyományos piacon. Nem fordul elö, hogy „nem jött el a kedvenc termelőm”, vagy nincs elegendő mennyiség egy keresett termékből etc. Ugyanakkor fontos kérdésként merül fel, hogy a bevásárló közösséghez csatlakozó termelő tudja-e produkálni a megrendelt mennyiséget. A rendszer lehetőséget biztosít a rendelés korlátozására, felfüggesztésére amennyiben nem teljesíthető a vásárlók igénye. Azonban nem szabad elfelejtenünk, hogy a fogyasztók felé negatív hatása lehet a kínálat hiányának. A konvencionális kereskedelemhez szokott fogyasztó a kínálatban a hiány fogalma lényegében ismeretlen. Ebből adódóan a bevásárló közösség azoknak az ős- és kistermelöknek jelent megjelenési felületet, akik folyamatosan tudják teljesíteni a megrendeléseket. A Kiskosár Bevásárló Közösségben szlovákiai és magyarországi termelők egyaránt értékesítenek. Az ősés helyi termelök számára a határon átívelö kereskedelem jogszabályi hátterének értelmezése ugyanakkor sok esetben megoldandó feladatként hárul a Bevásárló Közösség szervezőire.

A Kiskosár Bevásárló Közösség kínálatában a termelői piacokra jellemző termékeket találunk. Egy átalagos őszi hétvégén is közel 300 féle termék közül választhatunk (2.ábra).

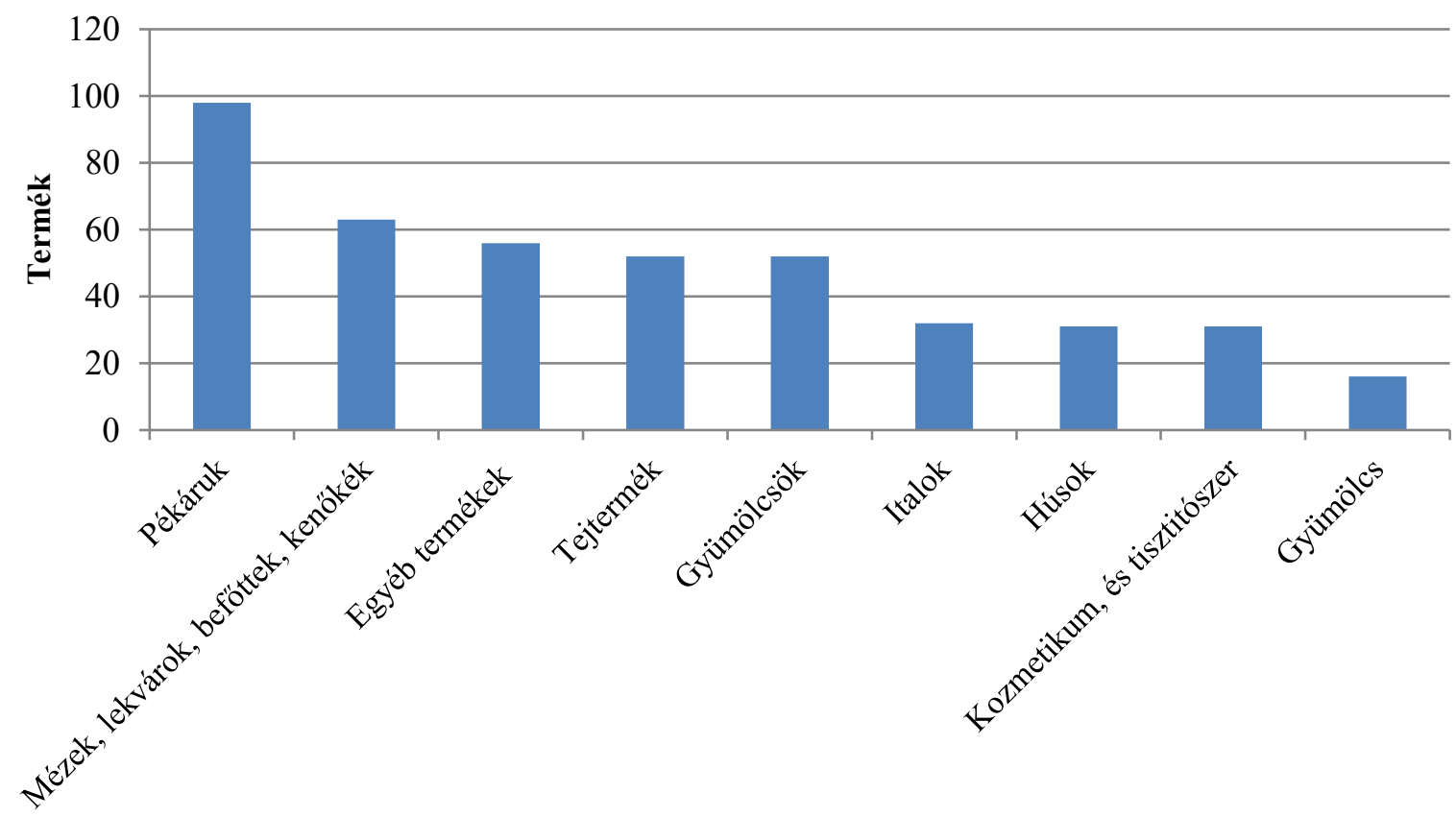

2. ábra. Kiskosár Bevásárló Közösség- Esztergom kínálata 2019. október 21

Forrás: https://kiskosarbolt.hu/pekaruk adatai alapján szerkesztett Kápolnai Zs. 


\section{Következtetések}

A gyakorlatban müködő bevásárló közösségek a helyi termelők támogatását, a vásárlók teljeskörü információkkal történő ellátását tartják a bevásárló közösségek jellemzőinek. A bevásárló közösséget a helyi termék értékesítésének egy formájaként is értelmezhetjük. A bevásárló közösségek önmeghatározásai alapvetően a tudatos vásárlást és a speciális végzett tevékenységeket emelik ki. A tudatos vásárlás egyfajta ideológia iránytüt mutat. Az együttgondolkodás alapvetéseit fogalmazza meg a közösségek számára, ideértve a termelöket és a vevőket is. Ennek fontos célja a lokális értékek fontosságának hangsúlyozása. A végzett tevékenységek közül a legfontosabb megkülönböztető karakter a termelők és vevők közötti kapcsolat biztosítása. A tapasztalat azt mutatja, hogy az előzetes rendelés az, ami leginkább megkülönbözteti a bevásárló közösséget a termelöi piacoktól.

Ha megpróbálunk keresni egy a valamennyi bevásárló közösségre értelmezhető tömör, érvényes meghatározást, akkor a bevásárló közösséget egy olyan, a rövid ellátási lánc fejlesztéséért elkötelezett szervezetként/ csoportosulásként kell meghatározni, mely marketing és kommunikációs eszközökkel segít kapcsolatot teremteni a termelök és a fogyasztók között, megjeleníti a kínálatot, valamint értékesítési csatornát (webshop, termelői piac és bolt) tart fenn.

A bevásárló közösségek gyakorlati müködésében fontos tanulság, hogy nem csupán kereskedelmi, árutermelési feladatokat látnak el, hanem különböző partnerségi kapcsolati hálókban közösségi, fenntarthatósági szemlélet- és értékformáló szerepet is betöltenek. Az egyes bevásárló közösségek müködésében és gyakorlatában vannak általános vonások, de egyedi elemek is. A fogalmi és jogi szabályozatlanság miatt merül fel jónéhány kérdés a minőség-ellenőrzés, az élelmiszerbiztonság és a számlavezetés biztonságának gyakorlatában. Pontosan ezek a tulajdonságok irányítják arra a figyelmet, hogy a bevásárló közösségek eredményes és fenntartható müködéséhez szükséges egy jól követhető müködési keret, fogalmi meghatározottság, ami jelenleg nincs meg.

\section{Irodalomjegyzék}

1. Benedek Zs.(2014): A rövid ellátási láncok hatásai. Összefoglaló a nemzetközi szakirodalom és a hazai tapasztalatok alapján. MTA Közgazdaság- és Regionális Tudományi Kutatóközpont Közgazdaság-tudományi Intézet, Budapest.48 p. ISSN 1785-377X

2. Berényi I. (1992): Szociálgeográfia. Budapest Elte-Eötvös Kiadó. 150 p.

3. BORSOD (2019): Borsodi kosár- és cserekör, https://www.facebook.com/magyararuk/posts/kedvesmindny\%C3\%A1janszervez $\% \mathrm{C} 3$ $\%$ BCnk-egy-termel $\% \mathrm{C} 3 \% \mathrm{~B} 5 \mathrm{i}-\mathrm{v} \% \mathrm{C} 3 \% \mathrm{~A} 1 \mathrm{~s} \% \mathrm{C} 3 \% \mathrm{~A} 1 \mathrm{rl} \% \mathrm{C} 3 \% \mathrm{~B} 3 \mathrm{i}-$ kos\%C3\%A1r-\%C3\%A9s-cserek\%C3\%B6rt-borsod-megy/589250614452504/, Letöltés: 2019. június 10.

4. Czene Zs.-Horkay N.-Ricz J. (2010): Helyi gazdaságfejlesztés Ötletadó megoldások, jó gyakorlatok. Budapest Területfejlesztési Füzetek 2. VÁTI Nonprofit Kft. Területi Tervezési és Értékelési Igazgatóság Stratégiai Tervezési és Vidékfejlesztési Iroda

5. DEBRECENI SZATYOR (2019):6. Piac, ahogy mi szerejük- Debreceni Szatyor. http://www.szatyordebrecen.hu/site/index.php?option=com_content\&view=article\&id $=3 \&$ Itemid=113, Letöltés: 2019 . július 20 .

6. Egyél velünk helyit. (2017): Lörinczi Zs. (szerk.) Esztergomi Környezetkultúra Egyesület Esztergom 58.p.

7. ÉN KOSARAM 2019 13. Az ÉN Kosaram Termelői és Kézműves Piaca, http://www.enkosaram.hu/page/homepage, Letöltés: 2019. június 3. 
8. ÉRD BEVÁSÁRLÓ KÖZÖSSÉG (2019):Önszervező Organikus Helyi Bevásárló Közösség, Érden, http://kornyezettudatoselet.hu/minden-ami-bio/bevasarlokozossegek/natur-kosar-bevasarlo-kozosseg, Letöltés: 2019. május 29.

9. G.Fekete É.(2014): Helyi termékek, szolgáltatások elismertségének erösítése a BorsodTorna-Gömör Akciócsoport területén. Miskolc Reg-Lex Bt. 150.p.

10. G.Fekete É.-Siposné Nándori E.: (2013): A társadalom térszerkezete. Miskolc 159 p.

11. Handlerné Makkos D.-Ónodi Zs.-Schwertner J.(2012): Kincs ami nincs- Esettanulmány mint módszer a helyi gazdaság-fejlesztési kezdeményezések értékelésében és tervezésében In.:Falu Város Régió 1-2. pp.25-32

12. Kajner P.- Lányi A.- Takács-Sánta A. (2013): A fenntarthatóság felé való átmenet jó példái Magyarországon. MIS-ÖKO Kft, Budapest

13. Kápolnai Zs. (2017): A kiskereskedelem és a szolgáltatások térbeli jellemzői Pest és Nógrád megye aprófalvaiban. A Falu. 2017 32/1.

14. Káposzta J. (2007): Regionális gazdaságtan. Szent István Egyetem Kiadó, Gödöllö pp.59-68 .

15. Kérdő A. (2008): A tartalomelemzés elmélete és gyakorlati alkalmazása, Budapesti Gazdasági Föiskola, szakdolgozat 57 p.

16. KISKOSAR (2019) Mi a bevásárló közösség? https://kiskosarbolt.hu/bevasarlokozosseg Letöltés: 2019. július 23.

17. Kujáni K. (2015): Hogyan müködik a rövid ellátási lánc Magyarországon előadás Kistermelői élelmiszerek útja a fogyasztókhoz. Hogyan müködik a rövid ellátási lánc? Országos nyári szakmai konferencia 2015. július 27. Környezettudatosság a mindennapokban

18. NYÍREGYHÁZI KOSÁR (2019): Nyíregyházi Kosár Közösség, http://www.nyiregyhazikosar.hu/, Letöltés: 2019. augusztus 2.

19. Rapkay B.- Illés S.-Stárics R. (2013): A helyi gazdaságfejlesztés egyes gondolati előzményei és következményei. In.:Földrajzi Közlemények.137. 1. 28-39.

20. Réthy K. - Dezsény Z..(2013): Közösség által támogatott mezőgazdaság, Budapest. ÖMKI, $27 \mathrm{p}$.

21. Ritter K.- Nagy H. - Tóth T.(2013): Hátrányos helyzetü vidéki térségek és helyi fejlesztési lehetőségeik egy észak-magyarországi példán keresztül.In.: Lukovics Miklós - Savanya Péter (szerk.):Új hangsúlyok a területi fejlödésben. JATEPress, Szeged pp. 224-242.

22. Szabó D. (2014): A rövid ellátási láncban rejlő lehetőségek és veszélyek Magyarországon In:.Acta Carolus Robertus 4. év. 2. szám ISSN 2062-8269

23. SZATYOR BOLT (2019a): Bevásárlóközösség összeköt amit a jó élelmiszerekről gondolunk, http://szatyorbolt.hu/bevasarlo-kozosseg, Letöltés: 2019. április 18.

24. SZATYOR BOLT (2019b): Szatyor bolt: bevásárló közösség, öko bolt és zöldcatering egyben, https://tudatosvasarlo.hu/cikk/szatyor-bolt-bevasarlo-kozosseg-oko-bolt-eszold-catering-egyben, Letöltés: 2019. július 10

25. SZATYOR EGYESÜLET (2019): Változások a bevásárlóközösségben egy fenntarthatóbb Szatyorért, http://szatyoregyesulet.hu/hu/valtozasok-a-bevasarlokozossegben/, Letöltés:2019. szeptember 5.

26. TATA BEVÁSÁRLÓ KÖZÖSSÉG (2019):Helyi bevásárló közösség szerveződik Tatán http://www.tata.hu/18193/helyi_bevasarlo_kozosseg_szervezodik_tatan, Letöltés: 2019. augusztus 14

27. TUDATOS VẢSÁRLÓ (2019a): Mit jelent a tudatos vásárlás? https://tudatosvasarlo.hu/tve/gyik Letöltés: 2019. szeptember 2. 
28. TUDATOS VÁSÁRLÓ (2019b): Müködő közösségi gazdaságok, dobozrendszerek és bevásárlóközösségek, https://tudatosvasarlo.hu/cikk/mukodo-kozossegi-gazdasagokdobozrendszerek-es-bevasarlokozossegek, Letöltés: 2019. augusztus 28.

29. Új Magyar Lexikon K-Me 4. kötet Akadémiai Kiadó, Budapest. 627.p.

30. Ujszászi E.(2013): Termelöi piac nyílik Csömörön In.:Csömöri Hírmondó XXI./8. pp. 12-13.

31. UNESCO (2009): A fenntartható fejlődés fogalma, célkitüzése, http://www.unesco.hu/termeszettudomany/fenntarthato-fejlodesre/fenntarthatofejlodes-091214, Letöltés: 2019. szeptember 15.

32. Vidékstratégia(2012): Nemzeti

Vidékstratégia

2012-2020, http://videkstrategia.kormany.hu/ Letöltés:2018 